\title{
BIOEDUSCIENCE
}

\author{
ISSN: 2614-1558
}

http://journal.uhamka.ac.id/index.php/bioeduscience

\section{Growth Response of Oval Red Cherry Tomatoes (Solanum lycopersicum Var. Cerasiforme) to Different Frequency of Watering}

\author{
Ambar Pratiwi ${ }^{1,2^{*}}$, Elisa Sastra ${ }^{1}$, Inggita Utami1,3 \\ 1Prodi Biologi Fakultas Sains dan Teknologi Terapan, Universitas Ahmad Dahlan Yogyakarta, Jl. Kapas No.9, Semaki, Kec. Umbulharjo, Kota \\ Yogyakarta, Daerah Istimewa Yogyakarta 55166 \\ ${ }^{2}$ Laboratorium Riset Biologi, Divisi Botani Fakultas Sains dan Teknologi Terapan Universitas Ahmad Dahlan Yogyakarta, Jl. Kapas No.9, \\ Semaki, Kec. Umbulharjo, Kota Yogyakarta, Daerah Istimewa Yogyakarta 55166 \\ ${ }^{3}$ Laboratorium Riset Biologi, Divisi Ekologi dan Sistematika Fakultas Sains dan Teknologi Terapan Univeritas Ahmad Dahlan Yogyakarta Jl. \\ Kapas No.9, Semaki, Kec. Umbulharjo, Kota Yogyakarta, Daerah Istimewa Yogyakarta 55166
}

*Correspondent Email: ambar@bio.uad.ac.id

Check for updates

\section{ARTICLE INFO}

Article history

Received: 17 Jan 2021

Accepted: 01 Nov 2021

Published: 31 Dec 2021

\section{Keywords:}

Oval red cherry tomatoes;

Plant growth;

Watering frequency;

\section{A B S T R A C T}

Background: Cherry tomatoes are horticultural plants with high economic value because the fruit has many benefits and uses. Tomato is a member of Solanaceae, which is susceptible to water shortages. The impact of drought has decreased tomato plants' growth, quality, and production. This research aims to determine the response of oval red cherry tomato plant growth to different watering frequencies and the frequency of oval red cherry tomato plants that show the best increase. Methods: In this research, the provision of different watering frequencies on oval red cherry tomato plants aged three weeks for 24 days. Tomato was watered frequently every day, once every three days, once every six days and nine days with a volume of $300 \mathrm{~mL}$ water. The parameters observed were the growth of oval red cherry tomatoes, including plant height, number of compound leaves, stem diameter, number of flowers and number of fruits, ascorbic acid and total flavonoid content. Results: The results showed that daily watering increased the number of leaves and stem diameter. Meanwhile, watered frequently at once every three days can increase the height of the oval red cherry tomato plants. Conclusions: The growth responses given to different watering frequencies were the increase in plant height, the number of compound leaves and the stem diameter of the oval red cherry tomatoes.

\section{Respon Pertumbuhan Tomat Ceri Merah Oval (Solanum lycopersicum Var. Cerasiforme)} Terhadap Frekuensi Penyiraman yang Berbeda

\section{A B S T R A K}

Background: Tomat ceri adalah tanaman hortikultura yang memiliki nilai ekonomis tinggi karena buahnya memiliki banyak manfaat dan kegunaan. Tomat adalah anggota Solanaceae yang rentan terhadap kekurangan air. Dampak kekeringan telah menurunkan pertumbuhan, kualitas dan produksi tanaman tomat. Penelitian ini bertujuan untuk menentukan respons pertumbuhan tanaman tomat ceri merah oval ke frekuensi penyiraman yang berbeda dan untuk menentukan frekuensi penyiraman tanaman tomat ceri merah oval yang menunjukkan pertumbuhan terbaik. Metode: Dalam penelitian ini, penyediaan frekuensi penyiraman yang berbeda pada tanaman tomat ceri merah oval berusia 3 minggu selama 24 hari. Tomat sering disiram setiap hari, setiap 3 hari sekali, setiap 6 hari sekali dan 9 hari dengan volume air $300 \mathrm{~mL}$. Parameter yang diamati adalah pertumbuhan tomat ceri merah oval termasuk tinggi tanaman, jumlah daun majemuk, diameter batang, jumlah bunga dan jumlah buah-buahan, dan juga asam askorbat dan kandungan flavonoid total. Hasil: Hasil penelitian menunjukkan bahwa penyiraman harian meningkatkan jumlah daun dan diameter batang. Sementara itu, sering disiram sekaligus setiap tiga hari dapat meningkatkan tinggi tanaman tomat ceri merah oval. Kesimpulan: Respons pertumbuhan yang diberikan pada frekuensi penyiraman yang berbeda adalah peningkatan tinggi tanaman, jumlah daun majemuk dan diameter batang tomat ceri merah oval. 


\section{Introduction}

Cherry tomatoes are horticultural plants with high economic value because the fruit of this plant has many benefits and uses. Manalu et al. (2019) stated that tomatoes of the cherry variety have higher protein, fat, carbohydrates, vitamin A, B, and vitamin C levels than regular tomatoes. In addition to being a vegetable, tomatoes can also be used as medicines, cosmetics, and food processing raw materials such as ketchup, cider, and others (Wijayanti and Susila, 2013). Lack of public knowledge about cherry tomatoes, low producers, and low quantity of production in Indonesia lead to high prices of cherry tomatoes. Today cherry tomatoes are often found in modern markets such as supermarkets and hypermarkets but are still rarely found in traditional markets. (Manalu et al., 2019). So that the production needs to be increased and developed.

Tomatoes are plants derived from the family Solanaceae susceptible to water shortages during infancy (Lestari; Jumawati et al., 2014). Drought events cause lack of water in plants. Drought is a condition where the soil water content is at a minimum condition for crop production growth (Purwanto and Agustono, 2010). Drought is a term to state if a plant experiences a lack of water from its environment. Drought checks on plants can be caused by a lack of water supply in the root area (Song and Banyo, 2011).

Research Jumawati et al (2014) showed that the rarer the tomato plant (Lycopersicum esculentum Mill) watered causes low growth and physiological components, but the quality of the fruit increases. Another study conducted by Nurul (2015), also stated that drought checks affect the average height of the plant, the number of fruits, the diameter of the fruit and the chlorophyll content of tomato leaves (Lycopersicum esculentum Mill). This is because the lack of water availability for plants causes the process of photosynthesis to decrease so that the need for plant growth is reduced, resulting in inhibition of plant growth (Dzajuli, 2010). Therefore, this study was conducted to find out the most optimal growth response and watering frequency to the growth of red cherry oval tomato plants (Solanum lycopersicum var. cerasiforme).

\section{Methods}

The study was conducted using a Complete Randomized Design (RAL) with one factor. These factors are the frequency of watering (once every day (P0), once every three days (P1), once every six days (P2), and once every nine days (P3)). Each treatment consists of 6 repeats, bringing 24 plant samples.

\section{Scope of Research}

Parameters observed include the growth of red cherry oval tomato plants in stem height, number of compound leaves, stem diameter, number of flowers, number of fruits, and total vitamin $\mathrm{C}$ and flavonoid content.

\section{Research Procedure}

Cherry tomato seedlings that have been three weeks old are treated for 24 days after planting (HST). Each seedling is planted in a polybag containing $4 \mathrm{~kg}$ of media. The treatment is given from watering frequency; every day (P0), once every three days (P1), six days once (P2), and once every nine days (P3). Each treatment consists of 6 repeats, bringing 24 plant samples.

\section{Data Collection and Data Analysis}

The parameters observed include the growth, number of compound leaves, the diameter of the stem, the number of flowers, the number of fruits, and measurements of the total vitamin $\mathrm{C}$ and flavonoid content carried out after harvest. Determination of vitamin content is done by titration method with $2.6 \mathrm{D}$ as a standard solution. Determination of total flavonoid content is determined by the aluminium chloride method. The data is analyzed statistically using variety analysis if there is a fundamental difference followed by the Duncan Multiple Range Test (DMRT) level of $5 \%$.

\section{Results}

The treatment that gave the highest average result was the watering frequency treatment once every three days with a high increase of $56.02 \mathrm{~cm}$. The treatment with the lowest average value was the watering frequency treatment for nine days with a high rise of $23.94 \mathrm{~cm}$. The frequency of watering once a day with the number of compounds leaves as many as 21 strands is the highest average value in this treatment table. In comparison, the lowest value is the treatment of watering frequency of 6 and 9 days with a compound number of 12.8 strands.

Table 1. Average height of red cherry oval tomato plant observation 24 HST

\begin{tabular}{cc}
\hline Watering Frequency & Average Height of Plants \\
\hline Daily (P0) & $(74,67 \pm 25,93)^{\mathrm{b}}$ \\
3 days once (P1) & $(76,75 \pm 17,09)^{\mathrm{b}}$ \\
6 days once (P2) & $(49,58 \pm 26,41)^{\mathrm{a}}$ \\
9 days once (P3) & $(43,67 \pm 20,68)^{\mathrm{a}}$ \\
\hline
\end{tabular}

Description: The number followed by the same letter in a row shows no real difference based on the 5\% DMRT test

Table 2. The average number of compound leaves of red cherry oval tomatoes observed 24 HST

$\begin{array}{cc}\text { Watering Frequency } & \begin{array}{c}\text { Number of compound leaves } \\ \text { (strands) }\end{array} \\ \text { Daily (P0) } & (21,17 \pm 5,98)^{\mathrm{b}} \\ 3 \text { days once (P1) } & (19,50 \pm 5,09)^{\mathrm{b}} \\ 6 \text { days once (P2) } & (12,83 \pm 5,23)^{\mathrm{a}} \\ 9 \text { days once (P3) } & (12,83 \pm 3,92)^{\mathrm{a}}\end{array}$

Description: The number followed by the same letter in a row shows no real difference based on the 5\% DMRT test 
Table 3. The average diameter of tomato stem red cherry oval observation 24 HST

\begin{tabular}{cc}
\hline Watering Frequency & $\begin{array}{c}\text { The average diameter of the rod } \\
(\mathrm{cm})\end{array}$ \\
\hline Daily (P0) & $(0,58 \pm 0,10)^{\mathrm{b}}$ \\
3 days once (P1) & $(0,57 \pm 0,09)^{\mathrm{b}}$ \\
6 days once (P2) & $(0,47 \pm 0,08)^{\mathrm{a}}$ \\
9 days once (P3) & $(0,46 \pm 0,03)^{\mathrm{a}}$ \\
\hline
\end{tabular}

Description: The number followed by the same letter in a row shows no real difference based on the 5\% DMRT test

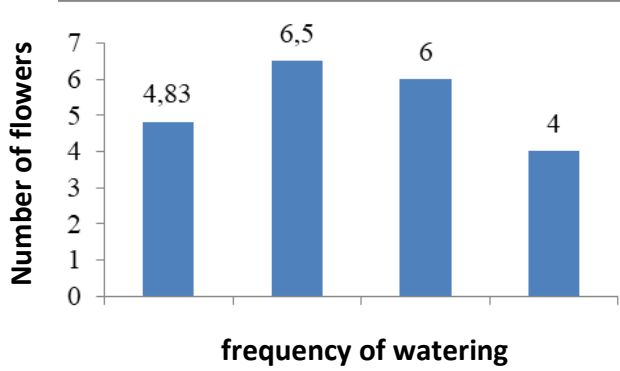

Figure 1. number of tomato flowers red cherry oval observation 24 HST

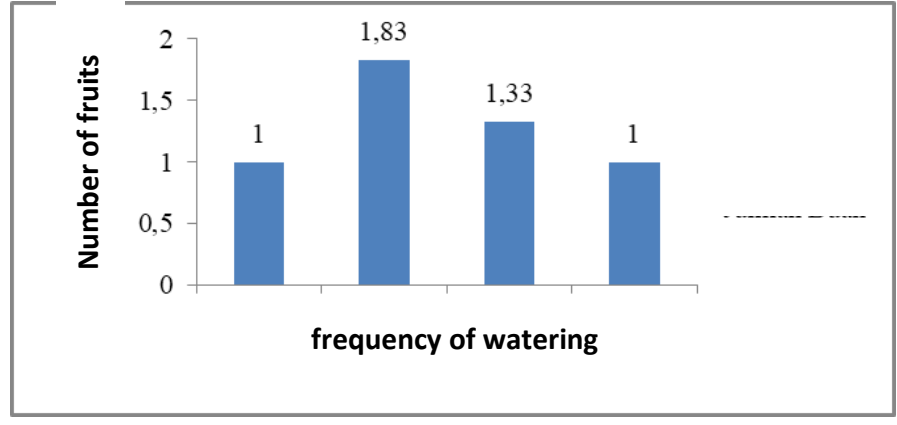

Figure 2. number of tomato fruits red cherry oval observation $24 \mathrm{HST}$

The treatment that gives the highest average value is the treatment of watering frequency once a day with a rod diameter of $0.58 \mathrm{~cm}$, while the treatment with the lowest average value is the treatment of watering frequency once every nine days with a rod diameter of $0.46 \mathrm{~cm}$.

Table 4. Total vitamin $\mathrm{C}$ and flavonoid content of red cherry oval tomatoes with variations in watering frequency

\begin{tabular}{ccc}
\hline $\begin{array}{c}\text { Watering } \\
\text { Frequency }\end{array}$ & Vit C $(\mathrm{mg} / 100 \mathrm{~g})$ & $\begin{array}{c}\text { Flavonoid total } \\
(\mathrm{mg} / 100 \mathrm{~g})\end{array}$ \\
\hline Daily (P0) & $(31,95 \pm 1,46)$ & $(27,32 \pm 0,11)$ \\
3 days once (P1) & $(38,30 \pm 1,55)$ & $(28,95 \pm 0,21)$ \\
6 days once (P2) & $(39,79 \pm 1,71)$ & $(25,46 \pm 0,22)$ \\
9 days once (P3) & $(39,85 \pm 1,61)$ & $(27,16 \pm 0,22)$ \\
\hline
\end{tabular}

\section{Discussion}

The observations showed that the increase in red cherry oval tomatoes is because of a different watering frequency treatment. The difference in the growth of red cherry oval tomato plants is caused by the availability of water for plants, which according to Marsha et al (2014), water is the main component of the plant body that has a primary function, including as a constituent of protoplasm that simultaneously maintains turgor cells. Cell turgidity is the pressure of the cell due to the entry of water into the cell. When water enters the cell, the turgor pressure increases, causing the plant cells to expand and reach their maximum size.

Based on the DMRT test in Table 1, the frequency of watering once every three days does not significantly differ with the red cherry oval tomato plant that is watered every day. Still, there is a substantial difference with watering frequency once every six days and once every nine days. This is because drought is an important abiotic factor associated with groundwater availability (Liu et al., 2013). According to Samanhudi (2010), dryness can interfere with the normal metabolism of plants, where water is the main element of plant cell division and enlargement, so that if the availability of water needed by plants is limited, then the growth of high plants will also be hampered.

\section{Number of Compound Leaves}

Leaves are plant organs where photosynthesis occurs. Photosynthesis that runs well will produce many photosynthetic (Priyanggi et al., 2019). Table 2 shows that the average number of compound leaves is treated the frequency of watering every day and the frequency of watering once every three days has a significant difference with red cherry oval tomato plants that are given the watering frequency treatment once every six days and once every nine days. Anggraini et al (2015) state that the first response that plants will experience in response to severe water deficit conditions is to close the stomata of the leaves.

The closure or narrowing of the stomata will cause inhibition of the process of photosynthesis that concerns the transportation of water in the plant body and decreased flow of carbon dioxide in the leaves (Song and Banyo, 2011). A decrease in the concentration of carbon dioxide in these leaves will affect the mobilization of starch and potentially increase respiration. To maintain the metabolic process, the plant will reduce carbohydrate reserves that cause the plant to experience a decrease in plant growth (Anggraini et al., 2015).

Helviana (2016) mentions that the number of leaves is also related to the height of the stems in plants. The higher the stem, the more leaves formed from the nodes (place of the leaf) contained in the stem. So that if more leaves are formed, then the process of photosynthesis will increase due to increased chlorophyll. The increasing photosynthesis results can lead to the formation of new leaves in plants.

\section{Trunk Diameter}

The measurements of the diameter of red cherry oval tomato stems showed different average values of each 
given watering frequency treatment as in Table 3. The average diameter of the stems based on an analysis of the data obtained showed that the red cherry oval tomato plant watered every day and once every three days had a significant difference to watering once every six days and once every nine days (Table 4). The more often the red cherry oval tomato plant is watered, the greater the diameter of the stem and vice versa. This is because water is the main factor used by plants in photosynthesis, where the availability of sufficient water will help plants more easily photosynthesize.

In the process of photosynthesis, this xylem and phloem tissue plays a role, where this xylem tissue serves to transport nutrients from the soil to leaves through the stem while the phloem tissue will transport photosynthetic results from the leaves to other organs such as stem roots and productive organs through phloem vessels (Lakitan, 2015). The results of this photostat will support the growth of the stem.

\section{Number of Flowers and Fruits}

Flowers are part of the plant, indicating that the plant has entered a sexual phase. In this study, observational data on the number of flowers can be seen in Figure 1, while the number of fruits can be seen in Figure 2. Based on Figure 1 and Figure 2, it can be seen that the highest average value is in the watering frequency treatment once every three days, while the lowest average value is in the treatment of watering frequency every day and once every nine days. This indicates that excess water becomes useless or inefficient for plant growth when the amount of water increases.

However, a decrease in photosynthetic activity due to lack of water availability will reduce photosynthetic, resulting in fewer flowers and fruit. Farooq et al. (2009) mention that plants that lack water supply or experience drought can cause a decrease in the time, number of seeds, flowering time and reproductive period in some plants. According to Song and Banyo (2011), plants that are given drought checks will decrease photosynthesis activity. Reduced photosynthesis activity will cause the number of fruits and the weight of the fruit to be lower.

\section{Total Vitamin C and Flavonoid Content}

Salinity can improve the quality of tomatoes (Jumawati et al, 2014), caused by increased solute through the arrangement of osmotic potential. Salinity can also increase the antioxidant content in the fruit (Gautier et al., 2010). The rarer the frequency of watering the range of vitamin C and flavonoids of tomatoes increases (Table 4.). This can be due to flavonoids and ascorbic acid acting as osmotic and antioxidant adjustment mechanisms.

A plant's response to salinity can be an increase in abscisic acid (ABA), just like the response to water stress.
Increased $\mathrm{ABA}$ is essential for rapid osmotic adjustment (Djukri, 2009). ABA causes the closure of the stomata and decreases the rate of photosynthesis. The decrease in the rate of photosynthesis will have an impact on the accumulation of osmolite or detoxification of ROS that support tolerance strategies (Osmolovskaya et al, 2018). In drought conditions, plants will produce and accumulate ROS (reactive oxygen species). ROS accumulation leads to oxidative decay, which impacts cell membrane damage, protein denaturation, and DNA (Li et al., 2019). Plants overcome the presence of ROS with antioxidant compounds in the form of enzymes superoxide dismutase (SOD), catalase and ascorbat peroxide) and non-enzymes (Kamanga et al., 2018). Examples of non-enzymatic antioxidant compounds are ascorbic acid, flavonoids: anthocyanins, catechins, betalain ( Li et al., 2019).

Less water is given, causing lower water potential. It synthesized antioxidant compounds such as ascorbic acid and flavonoids to maintain osmotic pressure and avoid oxidative damage.

\section{Conclusion}

Based on the results of research obtained, it was concluded that the red cherry oval tomato plant responds to the frequency of different watering in the form of a high increase of stems, the number of compound leaves, and stem diameter. The most optimal growth occurs at the frequency of daily watering, especially the rise in the number of compound leaves and the diameter of the stem.

\section{Declaration statement}

The authors reported no potential conflict of interest.

\section{References}

Anggraini, N., Faridah, E., dan Indrioko, S. 2015. Pengaruh Cekaman Kekeringan Terhadap Perilaku Fisiologis dan Pertumbuhan Bibit Black Locust (Robinia pseudoacacia). Jurnal Ilmu Kehutanan. 9(1): 40-56

Djukri. 2009. Cekaman Salinitas terhadap Pertumbuhan Tanaman. Prosiding Seminar Nasional Penelitian, Pendidikan dan Penerapan MIPA. Fakultas MIPA, Universiyas Negeri Yogyakarta. 16 Mei 2009. B-49 - B-55.

Dzajuli, Muhammad. 2010. Pengaruh Cekaman Kekeringan Terhadap Pertumbuhan dan Beberapa Karakter MorfoFisiologis Tanaman Nilam. Buletin Littro. 21(1): 8-17.

Farooq, M., Wahid, A., Kobayashi, N., Fugita, D., dan Basra, S.M.A. 2009. Plant Drought Stress: Effects, Mechanism and Management. Journal of Agronomy for Sustainable Development. 29(1): 185-212.

Gautier, H. F.L., Lauri, C. Massot., R. Mushed, I.Marty., D. Grassely, C. Keller, H. Sallanon, and M. Genard. 2010. Impact of ripening and salinity on tomato fruit ascorbat content and enzimatic activitis related to ascorbate recycling. Functional Plant Science and Biotechnology. 66-75.

Helviana, Roza, Sampurno dan Islan. 2016. Aplikasi Kompos Kulit Buah Kakao Pada Bibit Tanaman Kakao (Theobroma cacao L.). JOM FAPERTA. 3(2): 1-14. 
Jumawati R., Sakya, A. T., dan Rahayu M. 2014 Pertumbuhan Tomat Pada Frekuensi Pengairan yang Berbeda. Agrosains. 16(1): 13-18.

Kamanga, R.M., E. Mbega and P. Ndakidemi. 2018. Drought Tolerance Mechanisms in Plants: Physiological Responses Associated with Water Deficit Stress in Solanum lycopersicum. Advances in Crop Science and Technology. 6:362.

Lakitan, Benyamin. 2015. Dasar-Dasar Fisiologi Tumbuhan. Jakarta: Rajawali Press.

Li, G., X. Meng, M. Zhu, Z. Li. 2019. Research Progress of Betalain in Responsse to Adverse Stresses and Evolutionary Relationship Compared with Anthocyanin. Molecules. 24, 3078: 1-14.

Liu, X., Fan, Y., Wei, R., Kjelgren, R., Gong, C., dan Zhao, J. 2013. Effects of Soils Water and Nitrogen Availability on Photosynthesis and Water Use Efficiency of Robinia pseudoacacia Seedlings. Journal of Environmental Sciences. 25(3): 585-595.

Manalu, Grecya., Mariati., dan Rahmawati, Nur. 2019 Pertumbuhan Dan Produksi Tomat Cherry Pada Konsentrasi Nutrisi Yang Berbeda Dengan Sistem Hidroponik. Jurnal Agroteknologi FP USU. 7(1): 117-124.

Nurul, Anisa. 2015. Pengaruh Cekaman Kekeringan Terhadap Kandungan Senyawa Osmolit dan Perkembangan Buah Pada Tanaman Tomat (Lycopersicon Esculentum Mill.). Thesis. Universitas Negeri Yogyakarta. Yogyakarta.

Osmolovskaya, N., J Shumilina, A Kim, A Didio, T Grishina, T Bilova, O. A. Keltsieva, V Zhukov, I Tikhonovich, E Tarakhovskaya, A Frolov and L. A. Wessjohann. 2018. Methodology of Drought Stress Research: Experimental Setup and Physiological Characterization. International Journal of Molecular Sciences. 19, 4089

Priyanggi, R. W., Nugroho, R. A., dan Sari, Y. P. 2019. Pengaruh Rasio Pupuk Organik Cair Limbah Ikan Nila (Oreochromis niloticus) dengan Pupuk Organik Komersial Tehadap Pertumbuhan Sawi Pakcoy (Brassica rapa L.) Secara Hidroponik Rakit Apung. Bioprospek. 14(1): 11-22.

Purwanto dan Agustono, T. 2010 Kajian Fisiologi Tanaman Kedelai Pada Berbagai Kepadatan Gulma Teki dalam Kondisi Cekaman Kekeringan. Agroland. 17(2): 85-90.

Samanhudi. 2010. Pengujian Cepat Ketahanan Tanaman Sorgum Manis Terhadap Cekaman Kekeringan. Agrosains. 12(1): 913.

Song, Nio dan Banyo, Yunia. 2011. Konsentrasi Klorofil Daun Sebagai Indikator Kekurangan Air Pada Tanaman. Jurnal Ilmiah Sains. 11 (2): 169-170.

Wijayanti, E., dan Anas, D Susila. 2013 Pertumbuhan dan Produksi Dua Varietas Tomat (Lycopersicon esculentum Mill.) Secara Hidroponik dengan Beberapa Komposisi Media Tanam. Buletin Agrohorti. 1(1): 104-112. 